Article

\title{
Does Sustainability Engagement Affect Stock Return Volatility? Evidence from the Chinese Financial Market
}

\author{
Junru Zhang, Hadrian Geri Djajadikerta and Zhaoyong Zhang * \\ School of Business and Law, Edith Cowan University, Joondalup WA 6027, Australia; j.zhang@ecu.edu.au (J.Z.); \\ h.djajadikerta@ecu.edu.au (H.G.D.) \\ * Correspondence: zhaoyong.zhang@ecu.edu.au
}

Received: 28 July 2018; Accepted: 18 September 2018; Published: 20 September 2018

check for updates

\begin{abstract}
This paper examines the impact of firms' sustainability engagement on their stock returns and volatility by employing the EGARCH and FIGARCH models using data from the major financial firms listed in the Chinese stock market. We find evidence of a positive association between sustainability engagement and stock returns, suggesting firms' sustainability news release in favour of the market. Although volatility persistence can largely be explained by news flows, the results show that sustainability news release has the significant and largest drop in volatility persistence, followed by popularity in Google search engine and the general news. Sustainability news release is found to affect positively stock return volatility. We also find evidence that market expectation can be driven by the dominant social paradigm when sustainability is included. These findings have important implications for market efficiency and effective portfolio management decisions.
\end{abstract}

Keywords: corporate sustainability; news release; stakeholder theory; stock return volatility; EGARCH-m

\section{Introduction}

The growing international focus on corporate sustainability and social responsibility has triggered a trend toward requiring firms to engage corporate sustainable practices. However, the increase in attention from both industry and academia has led to an increasing number of studies on the association between sustainability engagement and firm risk (for instance, Feldman et al. [1]). According to Godfrey [2], sustainability engagement can provide insurance-like protection to preserve financial performance by generating moral capital and goodwill in the long term. Sustainability engagement can help reduce corporate adverse cash flow [3] and the cost of capital [4], as well as increase efficiency in waste reduction [5], control long-term risk, and refine long-term risk management [6]. Additionally, the existing literature shows that sustainability engagement can improve market confidence, thereby reducing stock market return risk through volatility. For instance, Harjoto and Jo [7] found that legalized sustainability exposure due to governmental requirements is in favour of the market because the information is more likely to be genuine and less costly to access. Theodoulidis et al. [8] indicated that sustainability engagement information increases market confidence as long-run-oriented business strategy eliminates stock market speculators. However, when a company discloses information about sustainability engagement, there are two general arguments among the existing studies about how the market interprets the information. First, the optimistic view highlights the importance of sustainability engagement in reducing stock market return volatility: even if sustainability information does not increase the present value of a company, it can potentially maximise future value by stretching the existing wealth creation of a business [9]. The commitment to sustainability can be captured by market participants over time, in which sustainability strategies and engagement can increase company 
performance in the long run, thereby increasing firm value and market confidence and reducing stock return volatility [4]. However, sustainability information can be influenced by information asymmetry in a semi-strong efficient market, causing investors to have dispersed opinion of the released sustainability information [7]. Market interpretation of sustainability information might lead to higher volatility in stock price return, because information released can be viewed as a strategy for management intrinsic values [10], thereby causing a bubble in stock prices [11].

In recent years the Chinese government has undertaken a series of initiatives and procedures encouraging firms to release sustainability reports. The two Chinese stock exchanges have also taken a leading role in requiring all listed companies to engage in environmental, social and governance (ESG) reporting since 2006. This study intends to examine the impact of such sustainability engagement through news releases on firms' stock return volatility, using data from the Chinese stock market. To form the basis of the theory behind this study, we consider two main views of sustainability and their association with stock return volatility; one is the information asymmetry view of sustainability associated with Crane [12] and Orlitzky [11], who suggest that the heterogeneous definitions of corporate social responsibility (CSR) can only exacerbate the problem of information asymmetry, in which case sustainability news is not different from other general news such as noise. The other view we consider is from Godfrey [2] and Jo and $\mathrm{Na}$ [10], where sustainability can reduce stock return volatility by providing shareholders with insurance-like protection for relationship-based intangible assets. By considering the background in China, we adopted the stakeholder theory from Freeman [13] with a view that powerful stakeholders are able to influence the dominant social paradigm, and therefore can alter the expectations of the market and drive corporate activities towards their expectations. We relate this study to the above arguments and believe they are not mutually exclusive, given a market that is stable in political turnover, where investors are influenced by the dominant social paradigm. In this context, social forces, sustainability dynamics and information can improve market confidence where there is information asymmetry. We consider the following theoretical grounds in this study. First, information asymmetry in a semi-strong market leads to information dispersal among investors, and in general bad news causes more volatility than good news. We argue that such an effect from information asymmetry can be reduced if a society is influenced substantively by its dominant social paradigm. Second, we relate the risk-reduction approach to the stakeholder theory to posit a negative association between sustainability engagement and stock return volatility.

Recently there have been studies on the relationship between news sentiment and changes in asset dynamics [14-17]. In particular, Riordan et al. [16] argue that, compared with positive messages, negative newswire messages are particularly informative and have a more significant impact on high-frequency asset price discovery and liquidity. Ho et al. [14] examined the dynamic relationship between firm-level return volatility and public news sentiment. Ho et al. [15] examined the impact of public information flows on the volatility of the bilateral Chinese RMB-U.S. dollar exchange rates in the spot, non-deliverable forward (NDF) and futures markets. The purpose of this study is to examine the impact from sustainability engagement information on firm stock return volatility, and to contrast the risk reduction effect against other types of news. In particular, to assess the impact of sustainability information on stock return volatility this study adopts the EGARCH variance-in-mean model to examine the association between sustainability engagement information and return volatility using data from the Chinese stock market. We find evidence of a positive association between sustainability engagement and stock returns. The results show that firms with higher frequencies of sustainability news release are associated with higher stock return, suggesting that the market takes firms' sustainability news release positively. This contrasts with the findings on market response to other types of general news releases. Sustainability news releases can reduce the volatility persistence and positively affect the return volatility. This study makes three major contributions. First, it provides new evidence in support of the stakeholder theory under the theoretical framework of market efficiency and information asymmetry. Second, it contributes to the existing 
debate on whether the market responds asymmetrically to sustainability news releases. Using data from the Chinese stock market, we find evidence that investors take firms' sustainability engagement information as a positive indicator of strong and healthy performance in the future. Finally, this study is among the first to collect and use daily news releases fitting into the concept of corporate sustainability and to document the dynamic effect of firms' sustainability engagement information on stock return volatility with robust results. These findings have important implications for the efficiency of the Chinese stock market and investors' effective portfolio investment decisions.

The remainder of the paper is structured as follows. Section 2 provides a brief literature review and proposes several hypotheses, followed by discussions on methodology and data in Section 3 . In Section 4, we discuss the empirical results. The last section concludes the paper.

\section{Literature Review and Empirical Predictions}

\subsection{Economic Consideration of Corporate Sustainability}

The concept of sustainability is derived from a normative concept, which occupies a continuum where it is understood quantitatively through an economic dimension, and qualitatively through a development dimension [18]. Economic-oriented considerations focus on the monetary terms and looking at economic growth related to corporate activities (i.e., whether sustainability adds financial benefits to shareholders); more precisely, sustainability adjudicates to stretch this wealth creation in the long run. In the modern economic model, sustainability is initially mentioned by DesJardins [19], but it is considered to constrain firms in profit maximization. This concept is then further extended to development, and the extension considers generating financial values without creating excessive environmental and social damage and aims to ensure that the firm is using natural resources without producing waste that exceeds the capacity at the expense of the ecological system [19]. In other words, there needs to be a balance between the growth of the economy and the development towards sustainability. Due to the unique institutional background in China, the perception of the social actors on corporate sustainability can be largely influenced by the dominant social paradigm, thereby incorporating sustainability into long-run business strategy and performance [18]. Corporate sustainability activities are assessed by whether they are translated into the long term through market-worthiness, creating reputation or maintaining legitimacy within the local community [20]. Companies' product chains and the associated natural resources inputs and outputs are severely influenced because they are framed by the dominant social paradigm in this institutional background [21].

In addition, the dominant social paradigm can shape and lead social action towards sustainability even if the movements do not fit perfectly into the theoretical concept of sustainability and generate short-term economic benefits [22]. An example is the valuation of social and human capital [23]. Although companies are required to report the social and human (labour) resources occupied in business operations, the legal requirements are largely linked to monetary terms that can hardly reflect the welfare situation of the reporting companies. For product responsibility, assessment of lifecycle is also an issue for many emerging economies, especially in China, which intensively uses resources obtained for low prices and produces exchange goods at higher prices. Due to the existence of these problems, the social actors (in this case, the reporting companies) are likely to focus solely on the dominant social paradigm and alter their understanding through disclosure about sustainability. The information exposure and corporate actions from the reporting companies are likely to be constrained by releasing information solely on the norms described in the paradigm, which may not often be related to corporate sustainability but what is required and expected by the government and political legitimacy. Similarly, the stakeholders may link information materiality with the extent to which companies have met and fulfilled the social paradigm in this context. In this study, we propose that the Chinese governing bodies are at a dominant level in the social paradigm, and market participants and corporate sustainability actions are framed by a certain higher-level social 
group in the economy. Given that the reporting requirements are derived from a political perspective (or considerations) on corporate sustainability, we posit that the market's expectation for material sustainability information is led by the dominant social paradigm in China.

\subsection{Institutional Background}

To address public concerns about environmental and social issues that have arisen both nationally and internationally, the Chinese government has undertaken a series of controls and initiatives to strengthen the concept of corporate sustainable development. In China, the notion of corporate sustainability reporting was first proposed in 2006 with the amendment of the Company Law of the People's Republic of China, Article 5 of the General Law. Later, in 2006, in the Chinese Communist Party's Sixth Plenary Session, the creation of a harmonious society was proposed with the focus of being socially responsible, particularly for business enterprises [24]. As a response to the national plan, both the Shanghai Stock Exchange (SHSE) and the Shenzhen Stock Exchange (SZSE) issued social reporting guidelines in 2006 and 2008, respectively, to create an appropriate system for corporate sustainability reporting. Although policies were introduced after the two stock exchanges announced their reporting guidelines, the meaning and definition of corporate sustainability were not clearly specified; in particular, there was no clear indication of how and what to report in a corporate sustainability disclosure [25]. To address further public concerns on the transparency of corporate sustainability information, in 2008 , both stock exchanges began setting mandatory corporate sustainability disclosures for a subset of listed companies, including the top 100 companies in the SZSE 100 index, companies in the SHSE Corporate Governance index firms listed in overseas stock markets, and all financial firms [26]. These requirements are important milestones in promoting and adopting sustainability reporting standards in China, and they are consistent with the goals and objectives of the government for building a harmonious socialist society by 2020. In the recent 19th CPC National Congress, President $\mathrm{Xi}$ specifically emphasized in his report the issues with the monotonous economic structure and the high carbon dependency in China. The Chinese government has drawn up a new blueprint in its national plan, vowing that "through the efforts of the concept of harmonious society, we will firmly establish a road of sustainable development with Chinese characteristics of conservation, recycling, low carbon, ecology, and environmental friendliness" [27]. A series of books and learning guides were published after the Congress, aiming to provide interpretation of the new measures and policies to be implemented by the government. Based on the series of policies and initiatives bonded with the national approach to sustainability, in this study we posit that the Chinese government includes corporate sustainability in the dominant social paradigm that influences social actors' decision-making.

\subsection{Information Asymmetry and Stakeholder Theory}

Even though the aim of sustainability is to generate a long-term business direction with less speculative behaviour, information asymmetry can cause sustainability information to become noise in an equity market. Corporate sustainability information is largely voluntary in most cases, so regulators may not have a strict approach to hard disclosure [28]. The flexibility in the voluntary form of sustainability information can be used as a manipulation of legitimacy by opportunistic management due to the misrepresentation of enforceable public accountability [29,30]. Investors can experience high information asymmetry in a market that is not fully efficient [7]. Studies have found that information misinterpretation can cause a reduction in stock price return and firm value. Under uncertain circumstances, investors can have a divergence of opinion about share prices, which leads to higher risk through return volatility and lower return [31]. Such divergence was later investigated by Grossman and Stiglitz [32], who found that the extent of disagreement is associated with the costs of information, e.g., information quality, information case, investment noise in risky assets and the number of investors involved. The study indicates that the scale of information can have a negative impact on the degree of divergence. Participants in the market are either unable or unwilling to screen out noise caused 
by information asymmetry. Another counter-sustainability argument indicates that investors are speculative so that they deliberately choose not to filter out noise from sustainability information, in which CSR actions are manipulation-prone for certain short-run company economic benefits [11].

However, the problem caused by information asymmetry can be reduced if the dominant social paradigm is able to provide market efficiency. Based on stakeholder theory, corporate sustainability not only relates to its shareholders/debt holders, but also to any relevant stakeholders [33]. The normative stakeholder theory asserts that "regardless of whether stakeholder management leads to improved financial performance, managers should manage the business for the benefit of all stakeholders" [34] (p. 32); however, from the positive branch, the more salient the stakeholder, the more efforts will be exerted in terms of satisfying their needs [35]. One major facet of stakeholder theory involves recognising and identifying the association between the behaviour of a company and its impact on company stakeholders [36]. Freeman [13] indicated that there are two types of stakeholders who are influential to companies. The primary stakeholders have the control of scarce resources that a company is dependent on to survive. The other type is defined as secondary stakeholders, who have less control over companies' decision-making. Under stakeholder theory, management will choose to meet the expectations of the primary stakeholders as a priority because the secondary stakeholders have limited resources that companies are dependent on. In the context of China, the government has great influence on companies' business activities and strategies, which has a significant impact on investment performance and financial returns $[37,38]$. The government policies are often used as directions for corporate investment [39]. Hence, we argue that since China has adopted corporate sustainability into the dominant social paradigm, companies are likely to engage in corporate sustainability in order to meet the expectations of the primary stakeholders. Being sustainable means that firms take a long-term view of their business actions rather than being speculative about short-term performance [26]; hence, the market is expected to respond favourably to sustainability news releases as they signal to investors that corporate decisions from the reporting firms are likely to link sound sustainable strategy with expected performance outcomes. Firms that integrate sustainability initiatives with their business strategies are more likely to gain a good reputation for social and environmental issues, which helps to mitigate risk. Vast existing research shows that sustainability-engaged firms are more likely to perform better financially in the long run [40-44]. Provided the market is efficient and the investors are rational, sustainability-engaged firms are more likely to perform well in the long run, which subsequently increases market confidence. As a consequence, it also reduces the potential speculative behaviour because, in the short term, sustainability engagement is costly and is at the expense of the shareholders [26]. Thus, it is believed that such "socially responsible" firms can help build shareholders' investment confidence and attract more funding at a lower cost of capital than "less responsible" firms [4]. Based on these arguments, we state the following hypothesis:

Hypothesis 1 (H1). Sustainability engagement increases market confidence and reduces speculation, thereby having a positive effect on stock return and decreasing return volatility.

There are some very important assumptions for our first hypothesis. First, whether sustainability is considered in the social paradigm is crucial in this study. In Section 2.2, we have listed several significant initiatives by the Chinese government towards sustainability. These include the 2006 National People's Congress, the 2006 Chinese Company Law, the 2006 SSE Corporate Environmental Responsibility Reporting Guidelines, the 2008 SZSE Corporate Social Responsibility Reporting Guidelines, and the 19th CPC National Congress. Also, another assumption is the existence of a dominant social paradigm in China; it has been shown by numerous existing studies that the government has a substantial influence on corporate business activities and corporate decision-making $[26,37,45,46]$. When we contrast the impact of other information on market participants due to information asymmetry, we expect that the market will respond differently to sustainability news and general news such that the impact on return volatility will also be different. 
Hypothesis 2 (H2). According to information asymmetry, market participants react more volatilely to negative than positive general news due to their potentially speculative behaviour in comparison with the response to sustainability news.

To test these hypotheses, in particular the dynamic relationship between sustainability engagement news and stock return volatility, we consider the generalized autoregressive conditional heteroskedasticity (GARCH) family model in this study. We first adopt the popular exponential GARCH (or EGARCH) specification for its ability to capture the most important stylized characteristics of volatility series, including asymmetry and leverage effects. We then consider the fractionally integrated generalized autoregressive conditional heteroscedastic (FIGARCH) models due to their long memory for examining persistence in stock return volatility. There are several existing studies that adopt volatility to determine the association with sustainability (see, for instance, Harjoto and Jo [7]; Jo and Na [10]; Becchetti et al. [47]), but few on the dynamics of conditional variance with daily stock return. This study is among the first to use daily sustainability news frequency as a proxy for corporate sustainability engagement to assess the impact on stock return volatility. For comparison purposes, we also use companies' general news frequency and Google search frequency to assess the impact.

\section{Sample and Methodology}

\subsection{Sample and Return Series}

This study examines the relationship between stock return volatility and sustainability news release of the listed financial firms in China. We obtained the daily stock price samples of the listed financial firms and their financial report information from the Bloomberg database. The sample period was 24 December 2007 to 21 March 2018. For sample selection, the initial sample included all the financial companies listed in both the Shanghai and the Shenzhen Stock Exchanges. We then excluded companies listed after 2008 (to ensure correct data on sustainability news releases) and those that were de-listed during the sample period. In addition, we also excluded listed companies that were relatively small in terms of total assets and market capitalization. This is because studies have found that sustainability engagements are positively associated with large firms both in terms of total assets [48] and market capitalisation [49]. As a result, our dataset consists of 30 listed financial companies with 80,190 daily observations in total, ranging from 1 December 2007 to 31 March 2018. The lists of our sample companies are shown in Appendixs A and B (Tables A1 and A2).

To mitigate the effect of size bias, we adopted a weighted approach to determine the stock return of the financial firms listed in the Chinese stock markets. The weight was assigned to each firm based on its market capitalization. This approach is supported by the stakeholder theory, which states that large entities are more likely to be influenced by stakeholder media [50], where instruments in communication are used to increase resources and corporate influences, leading to higher sensitivity to media exposure [51]. Let $S_{i t}$ denote firm $i$ 's stock price at time $t ; W I_{i t}$ be the weight at time $t$, and Market $c a p_{i t}$ be firm $i$ 's market capitalisation at time $t$. The stock return, $r_{i t}$, is calculated as follows:

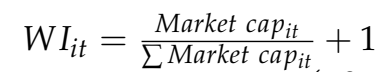

$$
\begin{aligned}
& r_{i t}=W I_{i t} \times 100 \times \log \left(\frac{S_{i, t}}{S_{i, t}-1}\right) .
\end{aligned}
$$

\subsection{Sustainability News Information Arrival}

The concept of sustainability development or corporate sustainability has been defined in various ways. The most commonly cited formulation for sustainability is provided by the World Commission on Environment and Development, that sustainable development shall "meet the needs of the present generation without compromising the ability of future generations to meet their own needs" [52] (p. 43). The interpretation of this definition is often related to human welfare and well-being, which should be 
sustained in the long run without raising concerns about impacts on future generations [53]. In this study, we apply these definitions of corporate sustainability to the case of China, defining the major sustainability themes promoted by the Chinese government as the indicative measures of corporate sustainability. Based on the long-term aims of sustainability and the concept of corporate sustainable development in the Chinese context, we define corporate sustainable news as information from news releases about a company's development that fits into the scale of the sustainability themes promoted by the government (environmental protection and social responsibility). To ensure that sustainability information is genuine, the news release must specify that the sustainability activities are associated with and have been integrated into the company's business strategies and operations.

To collect sustainability news information, we have used Bloomberg News, Baidu News search engine and Google News search engine in the data collection process. In particular, we first collected news from Baidu News and Google News search engines by using a series of keywords that fit into the concept of corporate sustainability. The key words were developed based on a series of themes under 'sustainable development' that were recently promoted by the 19th National Congress in China, which covers the main issues in environmental protections and social responsibility. Because news about our sample companies is often released in Chinese and English, we used both languages in our keyword search for sustainability news. These keywords used in Baidu News and Google news include social responsibility (社会责任), labour (劳工), human rights (人权), product responsibility (产品责任), economy (经济), environment (环境), ecology (生态), nature (自然), green (绿色), emissions reduction (减排), energy saving (节能), and environmental protection (环保). Then, we collected and manually processed all the keyword-related news based on firm, time and relevance to determine the frequency of each sample firm's daily news associated with its sustainability engagement. In order to differentiate sustainability news and other types of company news, we applied the following two criteria: First, the news must be related to a company's sustainability practices that are directly associated with the government's sustainable development policies. Second, the news must mention that such activities are a part of the company's sustainability business strategy, so that the sustainability practices reported in the news are reflections of sustainability through business operations (e.g., banks may apply screening when introducing products to promote customers' business ideas towards 'new energy'). If the news fits into the criteria, we record its frequency. It is also worth noting that our news frequency dataset does not include news reproduced or reprinted by other media to avoid double counting of the same news from the original media reporter.

Apart from Baidu News and Google News, we also used the Bloomberg News database. We first searched for Company News, then collected the sustainability news under the ESG (environment, social and governance) category based on our previous criteria, and finally recorded the number of daily news items associated with corporate sustainability. Similarly, we excluded news reproduced or reprinted by other media to avoid counting it twice. Consequently, the final sustainability news proxy includes the sum of the amount of news from all three databases. Again, we used the weighted sustainability news frequency (WSNF) in this study to accommodate the size effect. It is defined as:

$$
W S N F_{i t}=W I_{i t} \times S N F_{i t},
$$

where $S N F_{i t}$ is the sustainability news frequency for firm $i$, and $W I_{i t}$ is the weight for firm $i$ at time $t$.

\subsection{Other News Information Arrival}

To compare the news' influence on stock return volatility, we divided all news into sustainability news and other news information, which includes a company's general news and general public news of interest to the company. Companies' general daily news frequencies (GNF) were collected from the Bloomberg News database, which contains more than 1000 different news sources globally and over 90,000 web sources and social media. The major media include Dow Jones Newswires and the Wall Street Journal, as well as the central news agencies in China, e.g., The Central News 
Agency, Xinhua News Agency, China News Agency, and ENET Communication Agency. Due to the comprehensiveness of the Bloomberg database, the frequencies of companies' general news were directly collected from Bloomberg News Trend.

Recently, Internet usage has emerged as an important source of information for public opinion about a company's performance. Traditionally, people's interest in a topic is collected through surveys to measure the extent of awareness or support from the public for a decision made by a company [54]. However, as search engine technology develops, Google has become a reliable and valuable resource for people to obtain information, and it has become the most popular search engine in the world [55]. In this paper, to compare the sustainability news impact, we constructed a Google Trends Frequency index (GTF) as a proxy of public interest in a company's general business activities. It measures the popularity of a company in the Internet search, and ranges from zero to 100 based on the frequency of a search item relative to its previous-day 'popularity'. GTF is adopted as another proxy for news information arrival given its representation of people's interest about a topic or theme [56]. In particular, we entered a sample company's name in the search engine in English, Simplified Chinese and Traditional Chinese to collect all the search results, then processed the news and finally calculated the final GTF index for each sample company accordingly.

A weighted index was also adopted in the calculation of $G N F_{i t}$ and $G T F_{i t}$. At time $\mathrm{t}$, the weighted GNF and GTF are:

$$
\begin{aligned}
& W G N F_{i t}=W I_{i t} \times \log \left(G N F_{i t}\right) \\
& W G T F_{i t}=W I_{i t} \times \log \left(G T F_{i t}\right) .
\end{aligned}
$$

\subsection{Methodology and Model Specification}

To analyse the relationship between sustainability engagement news and stock return volatility over time, we considered the generalized autoregressive conditional heteroskedasticity (GARCH) family model in this study. Since the autoregressive conditional heteroskedasticity approach (ARCH) was first proposed by Engle [57], many significant theoretical and empirical developments have emerged in the literature [58-63]. GARCH family models have enjoyed popularity among academics because of their ability to capture some of the typical stylized facts of financial time series, such as volatility clustering [64], and also to take into account the feature of volatility over a long period of time and provide good in-sample estimates $[65,66]$. The symmetric univariate GARCH model originally proposed by Bollerslev [67] has been extended to incorporate various kinds of features, such as asymmetries, long memory persistence, and regime switches [63,68-70]. McAleer [71] reviews a wide range of models of financial volatility, univariate and multivariate, conditional and stochastic, and McAleer and Medeiros [70] discuss recent developments in modelling univariate asymmetric volatility.

The exponential GARCH (EGARCH) model proposed by Nelson [72] has become one of the two most widely estimated univariate asymmetric conditional volatility models for its ability to capture asymmetry and (possible) leverage [73,74]. Given that EGARCH is a discrete-time approximation to a continuous-time stochastic volatility process in logarithms, conditional volatility is guaranteed to be positive, but the model requires parametric restrictions to ensure that it can capture the (possible) leverage [73]. McAleer and Hafner [74] showed that EGARCH could be derived from a random coefficient complex nonlinear moving average (RCCNMA) process. Chang and McAleer [75] further derive the regularity conditions for asymmetry in EGARCH to show that, in practice, EGARCH always displays asymmetry, though not leverage. In order to testify the impact of condition volatility on stock return, a conditional variance term is added to the mean equation in the constructed EGARCH variance-in-mean model. In this study, we modify the EGARCH variance-in-mean model by adding the 
sustainability news variable into the mean equation in order to examine the hypothetical associations between stock return, volatility and sustainability news release [15], specified as follows:

$$
\begin{gathered}
r_{t}=b_{0}+b_{\lambda} h_{t}+b_{1} N e w s_{t}+\varepsilon_{t} \\
\varepsilon_{t}=\eta_{t} \sqrt{h_{t}}, \eta_{t}^{\text {iid }} \sim t(0,1, v) \\
\log \left(h_{t}\right)=\omega+\alpha \frac{\varepsilon_{t-1}}{\sqrt{h_{t-1}}}+\beta \log \left(h_{t-1}\right)+\gamma\left\{\left|\frac{\varepsilon_{t-1}}{\sqrt{h_{t-1}}}\right|-E\left(\left|\frac{\varepsilon_{t-1}}{\sqrt{h_{t-1}}}\right|\right)\right\},
\end{gathered}
$$

where $r_{t}$ is the daily return of stock price. News $s_{t}$ stands for the weighted daily sustainability news frequency $\left(W S N F_{t}\right)$, the weighted daily general news frequency $\left(W G N F_{t}\right)$, and the weighted Google Trends frequency $\left(W G T F_{t}\right)$, respectively, and $\varepsilon_{t}$ is the standard error at time. $h_{t}$ is the conditional volatility of $\varepsilon_{t}$ at time $t . \eta_{t}$ is the standardised residual of $\varepsilon_{t}$ with zero mean, one-unit standardisation in student-t distribution, where the degree of freedom is $v$. Lastly, in the variance equation, the coefficient $\beta$ captures the degree of volatility persistence that measures how quickly the present shock dissipates. EGARCH $(1,1)$ is covariance stationary if $\beta<1$; however, a relatively greater value in $\beta$ implicates the present shock will influence volatility in the long run [72]. Asymmetry exists for EGARCH if $\alpha \neq 0$, while the leverage effect exists if $\alpha<0$ and $\alpha<\gamma<-\alpha$ [74]. In the benchmark case that no news impact is examined, we should remove the news variable from the mean equation.

To address our research concerns and also serve as a robustness check of the EGARCH results, we then continued the study by employing the fractionally integrated GARCH (FIGARCH) to test the memory of the volatility of stock return. FIGARCH is based on the application of the fractional differencing operator to the autoregressive structure of the conditional variance by assuming that it follows a hyperbolic rather than exponential decay [76]. Extended from the family of GARCH models, Baillie et al. [76] proposed the FIGARCH model, which provides additional features for volatility clustering with good in-sample estimates [65,66]. Chang et al. [77] suggest that the FIGARCH $(1, \mathrm{~d}, 1)$ model outperforms its GARCH $(1,1)$ counterpart (see also Ho et al. [14]). Since the introduction of the model, many significant empirical studies on long memory have emerged in the existing literature [14,78-81]. In this study, we adopt FIGARCH to investigate the long-term memory in the conditional volatility of the stock return and how volatility persistence is affected by a firm's sustainability news releases and other firm-specific general news releases. We modify the FIGARCH $(1, d, 1)$ model by including the news variables as follows:

$$
\begin{gathered}
r_{t}=\mu+b_{1} \operatorname{News}_{t}+\varepsilon_{t}, \text { where } \varepsilon_{t}=\eta_{t} \sqrt{h_{t}}, \\
\mathrm{~b}(\mathrm{~L}) h_{t}=\omega+\left[b(L)-\varnothing(L)(1-L)^{d}\right] \varepsilon_{t}{ }^{2}, \\
b(L)=1-b_{1} L, \text { and } \varnothing(L)=1-\varnothing_{1} L,
\end{gathered}
$$

where $\varepsilon_{t}$ is the error at time $t, h_{t}$ is the conditional volatility of $\varepsilon_{t}$ at time $t, \eta_{t}$ is an identical and independent sequence following a specific distribution, $L$ is the lag operator, $(1-L)^{d}$ is the fractional differencing operator, and $d$ is the long-memory parameter. News $s_{t}$ stands for the weighted daily sustainability news frequency $\left(W S N F_{t}\right)$, the weighted daily general news frequency $\left(W G N F_{t}\right)$, and the weighted Google Trends frequency $\left(W G T F_{t}\right)$, respectively. The stationary long memory process for volatility is assessed through the parameter, $d$, which lies between 0 and 1 . The FIGARCH model offers higher flexibility when modelling conditional variables due to the nests of covariance stationary GARCH when $d=0$, where in the integrated GARCH (IGARCH), $d=1$. The IGARCH process seems to be too restrictive as it implies infinite persistence of a volatility shock and in most of the empirical situations the volatility process is found to be mean-reverting [76]. Under the FIGARCH model, the persistence of shocks to the conditional variance, which is also referred to as a long memory process of persistence, is captured by a fractional differencing parameter $d$ with a range from 0 to 1 . When $d=1$, a unit root is subjected, and it shows a permanent shock effect similarly to the IGARCH model; whereas when $d=0$, an ordinary GARCH process ensures that no long-memory persistence is involved [76]. The FIGARCH model implies a slower hyperbolic rate of decay for a lagged shock in 
the conditional variance equation so that the fractional differencing parameter provides important information about the pattern and speed with which shocks to volatility are propagated, which implies that the effect of a volatility shock is mean-reverting and is also quite persistent.

\section{Data Analysis and Implications}

\subsection{Descriptive Statistics}

Table 1 presents the descriptive statistics of the stock returns and news variables. Panel A reports the descriptive statistics of the daily stock returns of the financial companies. The mean return among the 30 sample firms is less than 0 , and the median of 0 confirms the negative average return. The standard deviations of the returns are 0.8487 and 0.6449 , indicating that they are considerably volatile. Both stock price returns are leptokurtic, indicating potential higher peak clustering, where the skewness of stock price return is slightly negative. The prices and daily returns of these stocks are presented in Figure 1. It can be seen that both stock prices and returns are more volatile during the Global Financial Crisis (GFC) period in 2008-2009 and also during China's stock market crash in the period 2015-2016. The stock prices are relatively flat during 2011-2015 (with the exception of 2013), as are the stock returns.

Table 1. Descriptive statistics of daily data.

\begin{tabular}{ccccccccc}
\hline Var. & Mean & Std. Dev & Median & Min. & Max. & Skew. & Kuro. & Obs. \\
\hline \multicolumn{7}{c}{ Panel A: Descriptive statistics of stock price return } \\
\hline$r_{t}$ & -0.0018 & 0.8487 & 0.0000 & -4.7958 & 4.2516 & -0.1240 & 7.4307 & 2673 \\
\hline \multicolumn{7}{c}{ Panel B: Descriptive statistics of news frequency } \\
\hline$S N F_{t}$ & 0.1349 & 0.1646 & 0.1000 & 0.0000 & 2.0000 & 3.0131 & 20.3135 & 2673 \\
$G N F_{t}$ & 5.9828 & 4.6825 & 4.6500 & 0.0000 & 32.7500 & 1.4506 & 5.5448 & 2673 \\
$G T F_{t}$ & 47.7899 & 15.3058 & 49.3681 & 9.0526 & 88.9474 & -0.2663 & 2.3256 & 2673 \\
\hline \multicolumn{7}{c}{ Panel C: Descriptive statistics of news variables } \\
\hline$W S N F_{t}$ & 0.1468 & 0.1796 & 0.1034 & 0.0000 & 2.1997 & 3.0795 & 21.2409 & 2673 \\
$W G N F_{t}$ & 1.4495 & 0.9289 & 1.5369 & -2.9957 & 3.4889 & -1.0312 & 5.2408 & 2673 \\
$W G T F_{t}$ & 3.8585 & 0.3744 & 3.9530 & 2.2450 & 4.5300 & -1.0619 & 3.7932 & 2673 \\
\hline
\end{tabular}

Note: Var. stands for variables. Std. Dev stands for standard deviation. Min. stands for minimum. Max. stands for maximum. Skew. stands for skewness. Kuro. stands for Kurtosis and Obs. stands for the number of observations. $\mathrm{rt}$ is the daily return of the sample financial firms. GNF $F_{t}$ is companies' general news frequency, and $W G N F_{t}$ is weighted general news frequency. $S N F_{t}$ is sustainability news frequency, including the frequency on news particularly regarding corporate sustainability. $W S N F_{t}$ is weighted sustainability news frequency. GTF $F_{t}$ is Google Trends frequency, indicating a popularity search index in Google about a company. WGTF $t$ is weighted Google Trends Frequency.

The descriptive statistics of all the news variables are shown in Panels B and C of Table 1. The mean of $G N F_{t}$ is 5.9828, with a range between 0 and 32.75. As for the weighted variable, the standard deviation of $W G N F_{t}$ drops substantially to 0.9289 , and the skewness changes from positive to slightly negative. For $S N F_{t}$, the mean is relatively low at 0.1349 compared to other general news, and the variable is significantly positively skewed, even using the weighted approach. GTF $F_{t}$ has a mean of 47.7899 , which indicates that sample companies are generally popular in a Google search. When we consider the weighted approach, the standard deviation of the variable is reduced to 0.3744 , in which a negative skewness is observed. 
Stock Price in Listed Financial Companies

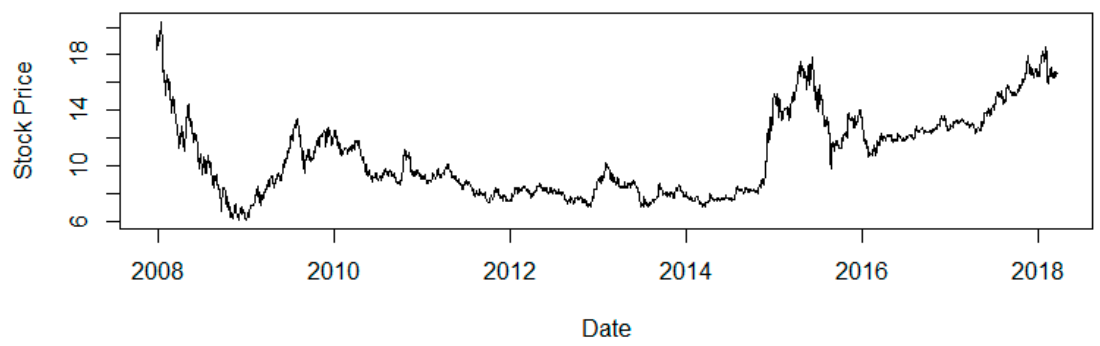

Return in Listed Financial Companies

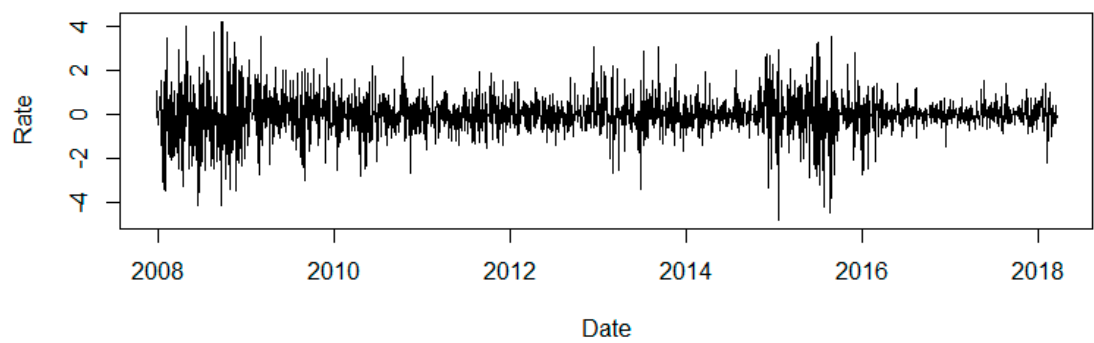

Figure 1. Daily stock price in financial companies and returns.

The frequencies of news releases of the three news variables are plotted in Figure 2. For sustainability news releases, the frequency was generally low during the GFC in 2008-2009, which may suggest that companies are less engaged in sustainability during the crisis periods. This was further shown in mid-2015 and 2016 during the Chinese stock market crisis, when the trends became lower and showed a flat pattern. Furthermore, the sustainability news frequency fluctuated extensively from 2010 to 2015. It is also noted that the peaks in sustainability news releases show some correspondence with the peaks in the stock prices particularly around 2013, 2014, 2016, and 2017. This preliminary visual observation indicates that there might be a positive association between sustainability news releases and firm stock prices. For $G N F_{t}$, the number of general news releases was generally low during the GFC period in 2008-2009, and a number of peaks were formed after the second half of 2010. Interestingly, the amount of company general news decreased extensively after the Chinese stock market crisis in 2016 when the stock price increased, while the amount of general news increased and fluctuated substantially between 2011 and 2015 when the stock price decreased. This observation may indicate that the financial firms are more inclined to release news when the stock price is low, whereas less news is released when the stock price is relatively high. Regarding Google searches, the overall trend is considerably stable during the sample period, with the exception of several notable drops. The frequency changes of Google searches show a similar pattern to the stock prices, suggesting that investors and business stakeholders or even the general public are more likely to use Google searches for company news when their stock prices are low. 
Sustainability News Freq. vs. General News Freq. vs. Google Trens Freq.

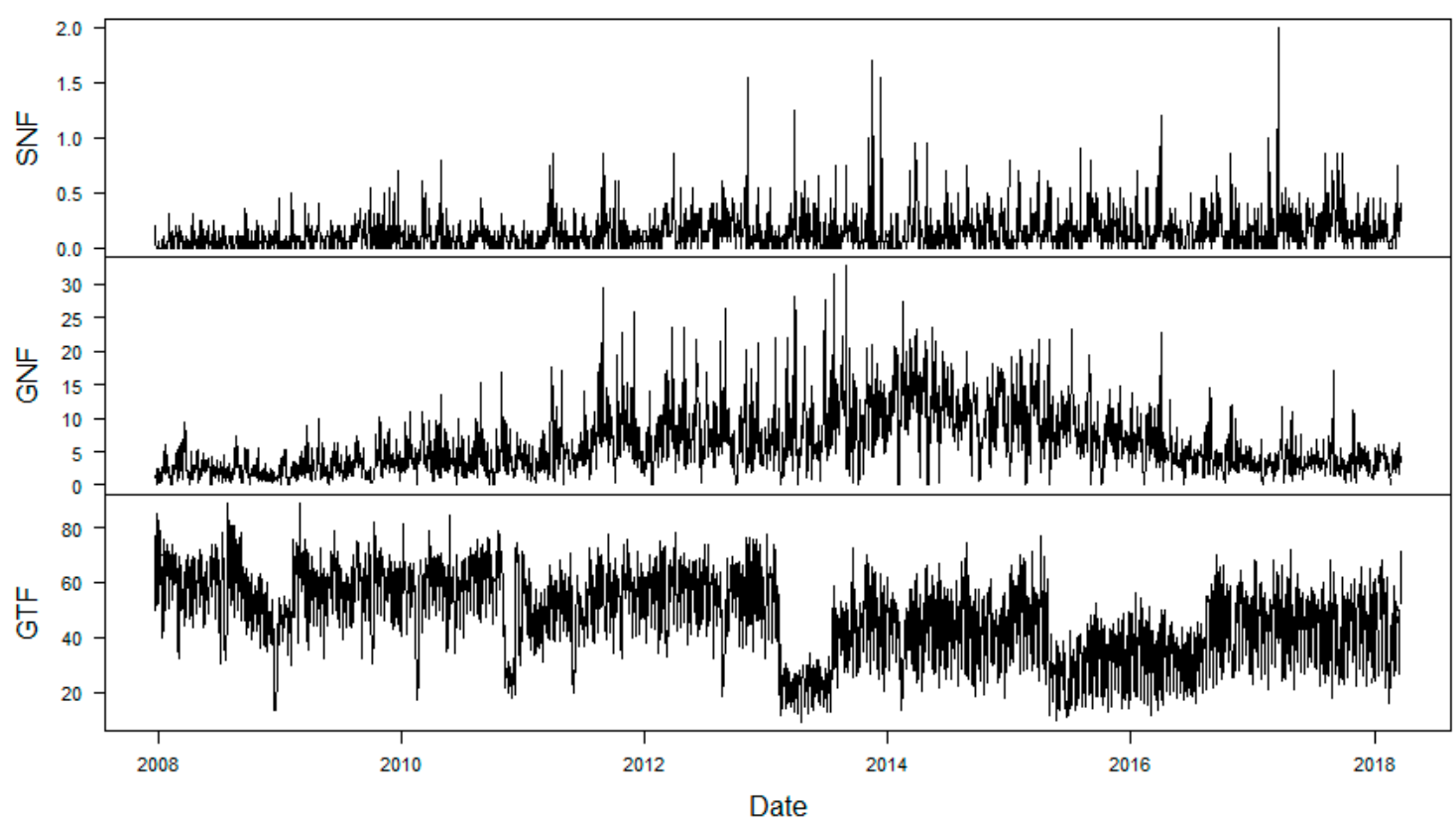

Figure 2. The number of sustainability news vs. general news vs. Google searches.

Given that the stock price returns are more volatile, especially during the GFC period in 2008-2009 and post-GFC in 2013, and the news variables do not show a distinctive pattern during the sample period, we follow Ho et al. [15] to assess if any distinctive patterns in the news series can be observed during the identified calm or turbulent state in stock returns by adopting a moving average window approach. It is arguable that volatility in a calm state is relatively smaller due to policies and regulation controls, whereas return in a turbulent state is more volatile. To investigate the relationship between the news variables and the stock return, we set the length of the moving window to 100 and calculate the mean of the first 100 observations. We then continue the process to calculate the mean of the 2nd to 101st observations and so on, until the mean of the last 100 observations is calculated. We plot the moving average of the news series and stock return in Figure 3, which will allow us to determine the different states based on the turning points. More specifically, we call the periods in which the moving average continues to increase the turbulent state, and the rest the calm state. It can be seen in Figure 3 that there is no steady pattern among the variables, with the exceptions of GNF/SNF and the return between 2008 and 2010. In contrast, the relationship between GTF and return shows a substantial fall during the same period. Hence, this study is less likely to be affected by policy switching and/or structural breaks. In addition, notably in Figure 3, the moving window shows a negative association between returns and SNF during the 2008-2009 GFC and the 2015-2016 financial market crisis in China. A possible explanation is that, during the crisis period, the market is more interested in information relating to firms' financial performance than to their sustainable practices; hence, the market is less reactive to sustainability disclosure [82]. This may also indicate that the market is more likely to have a diverse interpretation of information that is costly to access and to determine its genuineness [7]. As such, the market could not indicate whether sustainability engagement is truthful or bluffing. It may subsequently lead to different responses among the market participants, thereby increasing the volatility of the stock returns. It is also interesting to note that the extent of the negative association between return and SNF is relatively higher in the 2008-2009 GFC period than during the 2015-2016 crisis. This finding is consistent with our casual observation that sustainability in China has become a mega-trend, where investors and business stakeholders are more aware of sustainability issues and firms have become more critically observed by society, which has put more pressure on them to act in sustainable ways and prioritize sustainability engagement in their business operations. This pattern 
can also be observed when we compare the trend for the moving window between GNF and return, and that for GTF and return during the two crisis periods.
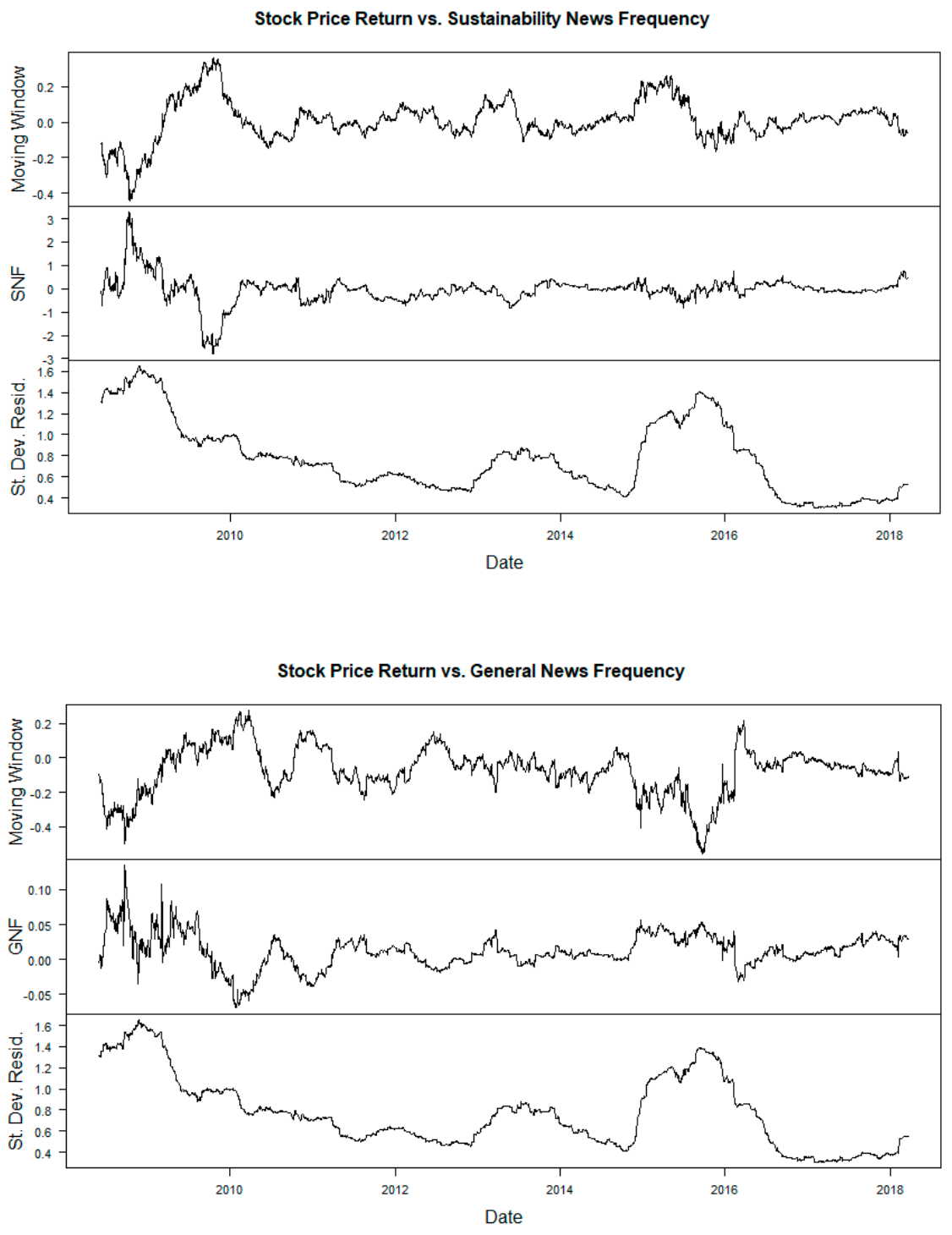

Stock Price Return vs. Google Trends Frequency

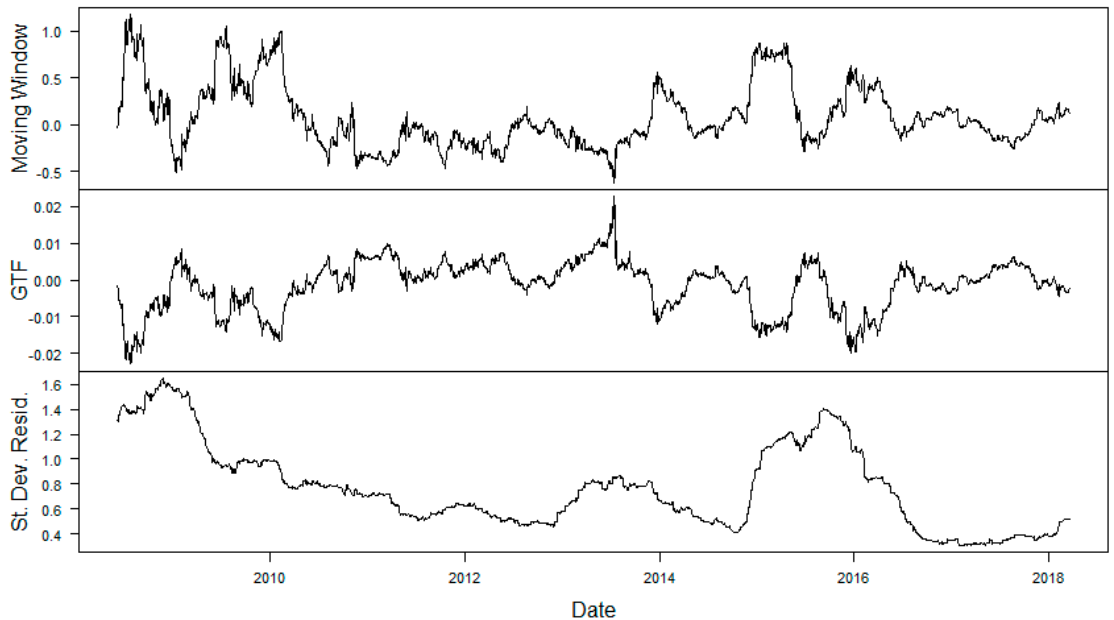

Figure 3. Moving average window of stock price return vs. news variables. 
It is also interesting to note that the relationship between stock returns and sustainability news release varies across the different states. Both are relatively less correlated in the turbulent state and highly correlated during the calm state. This pattern may be associated with investors' short-term opportunistic behaviour and the government's direct market intervention, especially during the turbulent state. On the other hand, the observed distinctive pattern between stock returns and sustainability news flows since 2011 becomes more visible, which may be associated with the dominant social paradigm since then. In contrast, the correlations between firm-specific general news and popularity in Google searches and the stock return are less noticeable.

\subsection{The EGARCH-M Framework}

We begin with an estimation of the benchmark model and then the full model to assess the news impact on stock return and volatility. The optimal ARMA orders are determined based on the Akaike Information Criterion (AIC). The estimation of the parameters of the model was undertaken through the conditional maximum likelihood method. The stock price returns are firstly fitted into the benchmark model (without news variable) and then the full model with news variable. The news variable in the full model is proxied by the sustainability news variable, the general news variable, and the Google search-based variable, respectively. Table 2 reports the results.

Table 2. Estimation results of the EGARCH-m model.

\begin{tabular}{ccccc}
\hline Parameter & Sustainability News (WSNF) & General News (WGNF) & Google Search (WGTF) & Benchmark Model \\
\hline $\mathbf{b}_{\mathbf{0}}$ (constant) & $0.0558(p=0.0000)$ & $0.5667(p=0.0000)$ & $4.0442(p=0.0000)$ & $0.0209(p=0.1098)$ \\
\hline $\mathbf{b}_{\boldsymbol{\lambda}}$ & $0.1743(p=0.0000)$ & $0.7709(p=0.0000)$ & $0.5595(p=0.0000)$ & $-0.0156(p=0.4209)$ \\
\hline $\mathbf{b}_{\mathbf{1}}$ & $2.9819(p=0.0000)$ & $1.7560(p=0.0000)$ & $2.2062(p=0.0000)$ & - \\
\hline$\omega$ (constant) & $-0.1231(p=0.0000)$ & $-0.2691(p=0.0000)$ & $-0.5206(p=0.0000)$ & $0.0070(p=0.0005)$ \\
\hline $\boldsymbol{\alpha}$ & $0.1601(p=0.0000)$ & $-0.1747(p=0.0000)$ & $-0.3292(p=0.0000)$ & $-0.0044(p=0.0000)$ \\
\hline $\boldsymbol{\beta}$ & $0.9679(p=0.0000)$ & $0.6388(p=0.0000)$ & $0.8177(p=0.0000)$ & $0.9934(p=0.0000)$ \\
\hline $\boldsymbol{L}$ Log lik. & $-0.0530(p=0.0000)$ & $0.0273(p=0.0982)$ & $-0.1063(p=0.0000)$ & $0.1284(p=0.0000)$ \\
\hline AIC & 1081.085 & 5567.7940 & 116.5570 & -2881.932 \\
\hline
\end{tabular}

Note: The table shows estimation results of the following EGARCH Variance-in-mean $(1,1)$ models. Log lik. is log likelihood. AIC is Akaike Information Criterion.

As shown in Table 2, the estimates of all the news variables are significantly positive. In comparison with the benchmark models, the log likelihood values are remarkably improved in the cases for the full models, and the values of the AIC also suggest that models with news variables, especially sustainability news, are preferred. More specifically, the results indicate that a sustainability news release can significantly increase stock returns. With the inclusion of the sustainability news variable, the persistence of the stock return volatility has been reduced to 0.9679 from 0.9934 , as in the case with the benchmark model. The results seem to suggest that the market responds favourably to firms' sustainability news releases, as the news signals to the investors that firms are engaged in sustainable strategies. The finding of a significant positive relationship between sustainability news and stock returns suggests that public exposure of a company's sustainability engagement through news releases can increase shareholders' investment confidence and help mitigate stock return volatility. This is consistent with our Hypothesis 1, which predicts a positive relationship between sustainability engagement, market confidence, and stock returns. The results lend support to the findings of Mehran [83] and Jenter and Kanaan [84], and confirm that sustainability engagement-related information will increase market confidence and have impacts on value creation as sustainability-integrated firms are viewed as being more likely to care about creating long-lasting financial success by implementing sustainability in their strategy. The results also support the argument that information asymmetry can be overcome by the dominant social paradigm if sustainability has been included. The results are consistent with existing studies where information about sustainability engagement is negatively associated with firm risk through volatility $[3,10]$. This is especially the 
case in China given its unique institutional features. As business activities are often influenced and to some extent driven by government policies [85], it is often observed that market performance is very sensitive to the direction changes of government policies. As such, with the recent promotion of "sustainable development" by the Chinese government, there would be a transition from the dominant social paradigm to the embodiment of the "sustaincentric paradigm" [86], a result of which would be a strong link between firms' sustainability engagement and stock returns as the market believes that sustainability-engaged firms will have high future returns. Furthermore, as sustainability engagement aims to boost wealth creation in the long term, decisions on sustainability engagement will strengthen asset performance in the future [18], which will lead to less speculative investment in the market and also help reduce return volatility. Therefore, we should accept our Hypothesis 1 given the evidence that news releases on corporate sustainability engagement increase market confidence, positively affect stock returns, and help reduce stock return volatility.

Similar results are found for the other two types of news variables. These findings confirm that news releases add explanatory power to the variance of stock returns, and are also consistent with the existing literature. The asymmetric effect is captured by $\alpha$. As can be seen in Table 2, all the estimates for $\alpha$ are significantly different from zero, confirming the existence of an asymmetric effect. In the sustainability news model, $\alpha$ is significantly positive at 0.1601 , and negative for the rest of the models, suggesting the presence of leverage effects in the models with general news and Google search news. As a special case of asymmetry, leverage captures the negative correlation between return shocks and subsequent shocks to volatility $[74,87]$. Our results provide further evidence that the stock return volatility is affected differently by positive and negative general news and Google search news, but is less likely to be affected by the sustainability news. This finding is consistent with existing studies on information asymmetry, where, in a semi-efficient market, investors are more responsive to negative news due to the management's speculative behaviour [11]. It also has important implications for firms' news release decisions as the market responds to different types of news differently. Under the notion of sustainable development, firms that engage sustainability outperform those less sustainable firms financially in the long run [4]. As such, the market participants would link sustainability engagement with corporate financial stability in the long run, which helps reduce speculative behaviour in the market, but it is not observed for the general news release. We find evidence that, due to the presence of asymmetric and leverage effects, the release of firm-specific general news and being 'popular' in a Google search may not always be favourable because negative news will cause increases in stock return volatility. In contrast, such leverage effect does not exist for sustainability news releases. In addition, sustainability news releases affect stock returns favourably, and the log likelihood values for the model with sustainability news variables are also remarkably improved compared to the benchmark model. This finding is consistent with stakeholder theory, and also with our Hypothesis 2 that market reaction is more volatile to negative than to positive general news in comparison with the response to sustainability news.

\subsection{The FIGARCH Framework}

To address our research concerns, and also as a robustness check for the EGARCH results, we continue this study by employing the FIGARCH framework to test the memory of the volatility of stock return. We fit our data into the FIGARCH specifications and reported the estimation results in Table 3. As can be seen in Table 3, the model without news variable has the largest estimate for the long memory parameter $\mathrm{d}$. When news variables are included, the volatility persistence is reduced to below 0.5. The results further suggest that volatility persistence is largely explained by news flows. However, the impact of different types of news on the persistence is different. It is found that sustainability news releases cause the largest drop in volatility persistence, followed by Google search engine and then general news. This finding is consistent with our early conclusion and supports Hypothesis 2. 
Table 3. Estimation results of the FIGARCH $(1, d, 1)$ model.

\begin{tabular}{ccccc}
\hline Parameter & Sustainability News (WSNF) & General News (WGNF) & Google Search (WGTF) & Benchmark Model \\
\hline M (constant) & $0.0066(p=0.0000)$ & $0.0055(p=0.0000)$ & $0.0092(p=0.0000)$ & $0.0224(p=0.1447)$ \\
b1 & $0.0233(p=0.0000)$ & $-0.0014(p=0.0000)$ & $-0.0107(p=0.0000)$ & - \\
$\omega$ (constant) & $0.0014(p=0.0000)$ & $0.0009(p=0.0000)$ & $-0.0001(p=0.1679)$ & $0.0022(p=0.0082)$ \\
$\alpha$ & $0.0423(p=0.0000)$ & $0.0353(p=0.0000)$ & $0.0449(p=0.0000)$ & $0.0000(p=1.0000)$ \\
$\beta$ & $0.9008(p=0.0000)$ & $0.9039(p=0.0000)$ & $0.9002(p=0.0000)$ & $0.9395(p=0.0000)$ \\
d & $0.4014(p=0.0000)$ & $0.4398(p=0.0982)$ & $0.4016(p=0.0000)$ & $0.7007(p=0.0000)$ \\
Log lik. & -4019.846 & -4036.078 & -4235.052 & -2884.184 \\
AIC & 3.0145 & 3.0266 & 3.1755 & 2.1640 \\
\hline
\end{tabular}

This table presents the summary output for FIGARCH $(1, \mathrm{~d}, 1)$ model fitted with normal distribution. $d$ is a factional differencing parameter. For the explanation of the variables, please see Table 1.

Thus, it has been demonstrated that news releases relating to corporate sustainability engagement will affect stock return positively and reduce the volatility persistence. The results are consistent with and support the stakeholder theory.

\section{Conclusions}

In this study we have empirically examined the impact of sustainability engagement information on financial firms' stock returns and volatility by employing the EGARCH-M and FIGARCH models using data from the Chinese stock market. We posit that market participants are less likely to face information asymmetry when they deal with sustainability engagement news, as sustainability is adopted in the dominant social paradigm in the context of China. Information asymmetry exists due to the cost, accessibility and reliability of the information. We hypothesize that the promotion of sustainable development by the Chinese government increases information credibility towards corporate sustainability engagement, and relevant news can effectively increase market confidence, thereby reducing market dispersion through stock return volatility. Using a sample of the Chinese listed financial firms during 2007-2018, we find evidence of a positive association between sustainability engagement and stock returns, which is consistent with our hypotheses. The results show that firms with higher frequencies of sustainability news releases are associated with higher stock returns, suggesting that the market looks favourably on firms' sustainability news releases and sustainability engagement increases market confident and reduces stock return volatility. This contrasts with the market response to other types of news flows such as firm-specific general news releases and popularity in Google search engine. It is also found that stock return volatility is influenced by all types of news, and the volatility persistence is substantially reduced after incorporating news variables, suggesting that volatility persistence is mostly explained by news flows. In particular, sustainability news releases have a greater impact on volatility persistence than the other two types of news releases, and there is no evidence indicating the presence of a leverage effect for sustainability news releases. This finding is consistent with our hypothesis of an asymmetric market reaction to positive and negative news associated with firm-specific general news releases and popularity news in Google search engine in contrast to the response to sustainability news.

The results also support the argument that information asymmetry can be overcome by the dominant social paradigm if sustainability has been included. This finding is consistent with our casual observation that, due to its unique institutional features, the Chinese government's recent promotion of "sustainable development" has caused a transition from the dominant social paradigm towards the embodiment of the "sustaincentric paradigm" [86], which would lead to a strong link between firms' sustainability engagement and stock returns. This will lead to less speculative investment in the market and hence to low return volatility. These findings imply that the market expectation can be driven by a social paradigm, given that sustainability is considered as a priority task by the government, and hence it has important implications for market efficiency and effective portfolio investment decisions.

Author Contributions: J.Z., H.G.D. and Z.Z. conceived the paper; J.Z. analysed the data; J.Z., H.G.D. and Z.Z. wrote and finalized the manuscript. All authors read and approved the final manuscript. 
Funding: This research received no external funding.

Acknowledgments: The authors wish to thank Michael McAleer, Alan Wong and the three anonymous referees for their constructive comments and suggestions, which have greatly improved the quality of the paper.

Conflicts of Interest: The authors declare no conflict of interest.

\section{Appendix A}

Table A1. Firm size of sample companies (total assets in millions of RMB).

\begin{tabular}{ccccccccccc}
\hline Date & Stock Code & & & & & & & & & \\
\hline & $\mathbf{0 0 0 0 0 1}$ & $\mathbf{0 0 2 1 4 2}$ & $\mathbf{6 0 0 0 0 0}$ & $\mathbf{6 0 0 0 1 5}$ & $\mathbf{6 0 0 0 1 6}$ & $\mathbf{6 0 0 0 3 6}$ & $\mathbf{6 0 1 0 0 9}$ & $\mathbf{6 0 1 1 6 9}$ & $\mathbf{6 0 1 3 2 8}$ & $\mathbf{6 0 1 6 0 1}$ \\
\hline 2007 & 352.54 & 75.511 & 914.98 & 592.34 & 918.83 & 1310.96 & 76.06 & 354.22 & 2110.44 & 322.34 \\
2008 & 474.44 & 103.26 & 1309.43 & 731.63 & 1054.35 & 1571.79 & 93.70 & 417.02 & 2556.41 & 317.89 \\
2009 & 587.81 & 163.35 & 1622.72 & 845.45 & 1426.39 & 2067.94 & 149.56 & 533.46 & 3309.13 & 397.18 \\
2010 & 727.21 & 263.27 & 2191.41 & 1040.23 & 1823.73 & 2402.50 & 221.49 & 733.21 & 3951.59 & 475.71 \\
2011 & 1258.18 & 260.50 & 2684.69 & 1244.14 & 2229.06 & 2794.97 & 281.79 & 956.49 & 4611.17 & 570.61 \\
2012 & 1606.54 & 372.70 & 3145.71 & 1488.86 & 3212.00 & 3408.09 & 343.79 & 1119.96 & 5273.37 & 681.50 \\
2013 & 1891.74 & 462.19 & 3680.13 & 1672.44 & 3226.21 & 4016.39 & 434.05 & 1336.76 & 5960.93 & 723.53 \\
2014 & 2186.46 & 554.11 & 4195.92 & 1851.62 & 4015.13 & 4731.82 & 573.15 & 1524.43 & 6268.29 & 825.10 \\
2015 & 2507.145 & 716.46 & 5044.35 & 2020.60 & 4520.68 & 5474.97 & 805.02 & 1844.90 & 7155.36 & 923.84 \\
2016 & 2953.43 & 885.02 & 5857.26 & 2356.23 & 5895.87 & 5942.31 & 1063.90 & 2116.33 & 8403.16 & 1020.69 \\
\hline & $\mathbf{6 0 1 1 6 6}$ & $\mathbf{6 0 1 9 3 9}$ & $\mathbf{6 0 1 9 8 8}$ & $\mathbf{6 0 1 9 9 8}$ & $\mathbf{6 0 1 3 9 8}$ & $\mathbf{6 0 1 6 2 8}$ & $\mathbf{6 0 0 8 3 7}$ & $\mathbf{6 0 1 3 1 8}$ & $\mathbf{6 0 0 0 3 0}$ & $\mathbf{6 0 0 3 6 9}$ \\
\hline 2007 & 851.34 & 6598.18 & 5991.22 & 1011.18 & 8683.71 & 933.70 & 95.34 & 692.22 & 189.65 & - \\
2008 & 1020.90 & 7555.45 & 6951.68 & 1319.57 & 9757.14 & 987.49 & 74.68 & 704.56 & 206.80 & 8.02 \\
2009 & 1332.16 & 9623.36 & 8751.94 & 1775.03 & $11,785.05$ & 1226.25 & 120.73 & 935.71 & 153.17 & 14.97 \\
2010 & 1849.67 & $10,810.32$ & $10,459.87$ & 2081.31 & $13,458.62$ & 1410.57 & 115.41 & 1171.62 & 148.28 & 22.77 \\
2011 & 2408.80 & $12,281.83$ & $11,829.79$ & 2765.88 & $15,476.86$ & 1583.90 & 98.97 & 2285.42 & 168.50 & 17.76 \\
2012 & 3250.98 & $13,972.83$ & $12,680.62$ & 2959.93 & $17,542.21$ & 1898.91 & 126.48 & 2844.26 & 271.35 & 17.25 \\
2013 & 3678.30 & $15,363.21$ & $13,874.30$ & 3641.19 & $18,917.75$ & 1972.94 & 169.12 & 3360.31 & 479.62 & 29.99 \\
2014 & 4406.40 & $16,744.09$ & $15,251.38$ & 4138.81 & $20,609.95$ & 2246.56 & 352.62 & 4005.91 & 616.10 & 58.20 \\
2015 & 5298.88 & $18,349.49$ & $16,815.60$ & 5122.29 & $22,209.78$ & 2448.31 & 576.44 & 4765.15 & 597.43 & 71.74 \\
2016 & 6085.90 & $20,963.71$ & $18,148.89$ & 5931.05 & $24,137.26$ & 2696.95 & 560.86 & 5576.90 & 189.65 & 70.99 \\
\hline
\end{tabular}

\section{Appendix B}

Table A2. Firm size of sample companies (market capitalisation in millions of RMB).

\begin{tabular}{|c|c|c|c|c|c|c|c|c|c|c|}
\hline Date & Stock Code & & & & & & & & & \\
\hline & 000001 & 002142 & 600000 & 600015 & 600016 & 600036 & 601009 & 601169 & 601328 & 601601 \\
\hline 2007 & 80.76 & - & 229.94 & 80.47 & 214.58 & 556.59 & 35.081 & 126.79 & 639.48 & 380.77 \\
\hline 2008 & 2.94 & 17.00 & 75.01 & 36.28 & 76.61 & 180.14 & 15.410 & 55.49 & 236.46 & 85.62 \\
\hline 2009 & 75.70 & 43.73 & 191.52 & 61.98 & 175.30 & 344.65 & 35.54 & 12.04 & 425.43 & 220.80 \\
\hline 2010 & 55.03 & 35.76 & 177.78 & 54.40 & 136.66 & 291.35 & 29.51 & 71.24 & 339.02 & 207.31 \\
\hline 2011 & 79.87 & 26.42 & 158.37 & 76.92 & 155.57 & 259.50 & 27.55 & 57.79 & 275.04 & 162.24 \\
\hline 2012 & 82.08 & 30.74 & 185.04 & 70.89 & 219.184 & 296.70 & 27.31 & 81.84 & 358.38 & 205.41 \\
\hline 2013 & 100.42 & 26.62 & 175.90 & 76.31 & 213.213 & 283.85 & 24.02 & 66.10 & 300.21 & 182.35 \\
\hline 2014 & 180.97 & 51.12 & 292.67 & 119.86 & 351.531 & 413.75 & 43.49 & 115.42 & 469.83 & 290.60 \\
\hline 2015 & 171.56 & 60.49 & 340.80 & 129.72 & 329.453 & 441.44 & 59.59 & 133.44 & 412.80 & 255.54 \\
\hline 2016 & 156.26 & 64.89 & 350.43 & 115.94 & 317.773 & 437.77 & 65.68 & 148.42 & 402.27 & 241.77 \\
\hline \multirow[t]{2}{*}{2017} & 228.37 & 90.29 & 369.54 & 115.40 & 293.156 & 717.57 & 65.65 & 151.17 & 368.74 & 375.35 \\
\hline & 601166 & 601939 & 601988 & 601998 & 601398 & 601628 & 600837 & 601318 & 600030 & 600369 \\
\hline 2007 & 259.30 & 1468.28 & 1443.64 & 328.35 & 2471.79 & 1485.46 & 225.94 & 706.49 & 295.95 & 2.22 \\
\hline 2008 & 73.00 & 875.47 & 670.58 & 131.74 & 1186.85 & 542.69 & 66.727 & 211.77 & 119.15 & 1.73 \\
\hline 2009 & 201.55 & 1375.34 & 1051.10 & 291.58 & 1836.22 & 911.17 & 157.89 & 416.88 & 210.65 & 36.15 \\
\hline 2010 & 144.12 & 1464.68 & 922.21 & 192.81 & 1537.88 & 643.84 & 79.32 & 479.34 & 125.22 & 27.01 \\
\hline 2011 & 135.05 & 1100.50 & 764.92 & 181.65 & 1436.39 & 483.21 & 60.97 & 294.82 & 107.75 & 20.04 \\
\hline 2012 & 180.03 & 1247.06 & 803.68 & 193.08 & 1474.73 & 597.07 & 98.91 & 380.17 & 150.02 & 20.74 \\
\hline 2013 & 193.19 & 1137.55 & 745.87 & 172.38 & 1302.25 & 455.91 & 107.33 & 369.40 & 144.90 & 23.06 \\
\hline 2014 & 314.36 & 1290.58 & 1143.75 & 333.81 & 1682.45 & 892.52 & 218.02 & 593.40 & 361.07 & 62.91 \\
\hline 2015 & 325.22 & 1124.09 & 1087.37 & 292.89 & 1574.85 & 745.55 & 167.12 & 658.05 & 224.93 & 55.89 \\
\hline 2016 & 307.50 & 1336.77 & 982.49 & 283.94 & 1550.20 & 636.17 & 168.04 & 642.42 & 190.14 & 40.25 \\
\hline 2017 & 352.95 & $14,499.25$ & 1104.18 & 199.71 & 2126.29 & 577.94 & 136.35 & 1238.572 & 219.32 & 26.14 \\
\hline
\end{tabular}




\section{References}

1. Feldman, S.J.; Soyka, P.A.; Ameer, P.G. Does improving a firm's environmental management system and environmental performance result in a higher stock price? J. Investig. 1997, 6, 87-97. [CrossRef]

2. Godfrey, P.C. The relationship between corporate philanthropy and shareholder wealth: A risk management perspective. Acad. Manag. Rev. 2005, 30, 777-798. [CrossRef]

3. Sharfman, M.P.; Fernando, C.S. Environmental risk management and the cost of capital. Strateg. Manag. J. 2008, 29, 569-592. [CrossRef]

4. Dhaliwal, D.S.; Li, O.Z.; Tsang, A.; Yang, Y.G. Voluntary nonfinancial disclosure and the cost of equity capital: The initiation of corporate social responsibility reporting. Account. Rev. 2011, 86, 59-100. [CrossRef]

5. Ratnatunga, J.; Jones, S. An inconvenient truth about accounting: The paradigm shift required in carbon emissions reporting and assurance. In Contemporary Issues in Sustainability Accounting, Assurance and Reporting; Emerald Group Publishing: Bradford, UK, 2012; pp. 71-114.

6. Dhaliwal, D.S.; Radhakrishnan, S.; Tsang, A.; Yang, Y.G. Nonfinancial disclosure and analyst forecast accuracy: International evidence on corporate social responsibility disclosure. Account. Rev. 2012, 87, 723-759. [CrossRef]

7. Harjoto, M.A.; Jo, H. Legal vs. Normative CSR: Differential Impact on Analyst Dispersion, Stock Return Volatility, Cost of Capital, and Firm Value. J. Bus. Ethics 2015, 128, 1-20. [CrossRef]

8. Theodoulidis, B.; Diaz, D.; Crotto, F.; Rancati, E. Exploring corporate social responsibility and financial performance through stakeholder theory in the tourism industries. Tour. Manag. 2017, 62, 173-188. [CrossRef]

9. Mackey, A.; Mackey, T.B.; Barney, J.B. Corporate social responsibility and firm performance: Investor preferences and corporate strategies. Acad. Manag. Rev. 2007, 32, 817-835. [CrossRef]

10. Jo, H.; Na, H. Does CSR Reduce Firm Risk? Evidence from Controversial Industry Sectors. J. Bus. Ethics 2012, 110, 441-456. [CrossRef]

11. Orlitzky, M. Corporate social responsibility, noise, and stock market volatility. Acad. Manag. Perspect. 2013, 27, 238-254. [CrossRef]

12. Crane, A. The Oxford Handbook of Corporate Social Responsibility; Oxford Handbooks: Oxford, UK, 2008.

13. Freeman, R.E. The politics of stakeholder theory: Some future directions. Bus. Ethics Q. 1994, 4, 409-421. [CrossRef]

14. Ho, K.-Y.; Shi, Y.; Zhang, Z. How does news sentiment impact asset volatility? Evidence from long memory and regime-switching approaches. N. Am. J. Econ. Financ. 2013, 26, 436-456. [CrossRef]

15. Ho, K.-Y.; Shi, Y.; Zhang, Z. Does news matter in China's foreign exchange market? Chinese RMB volatility and public information arrivals. Int. Rev. Econ. Financ. 2017, 52, 302-321. [CrossRef]

16. Riordan, R.; Storkenmaier, A.; Wagener, M.; Zhang, S.S. Public information arrival: Price discovery and liquidity in electronic limit order markets. J. Bank. Financ. 2013, 37, 1148-1159. [CrossRef]

17. Tetlock, P.C. Does public financial news resolve asymmetric information? Rev. Financ. Stud. 2010, 23, 3520-3557. [CrossRef]

18. Lu, Y.; Abeysekera, I. What do stakeholders care about? Investigating corporate social and environmental disclosure in China. J. Bus. Ethics 2017, 144, 169-184. [CrossRef]

19. DesJardins, J. Corporate environmental responsibility. J. Bus. Ethics 1998, 17, 825-838. [CrossRef]

20. Chow, W.S.; Chen, Y. Corporate sustainable development: Testing a new scale based on the mainland Chinese context. J. Bus. Ethics 2012, 105, 519-533. [CrossRef]

21. Korhonen, J. The dominant economics paradigm and corporate social responsibility. Corp. Soc. Responsib. Environ. Manag. 2002, 9, 66-79. [CrossRef]

22. Korhonen, J. Should we measure corporate social responsibility? Corp. Soc. Responsib. Environ. Manag. 2003, 10, 25-39. [CrossRef]

23. Jha, A.; Cox, J. Corporate social responsibility and social capital. J. Bank. Financ. 2015, 60, 252-270. [CrossRef]

24. Gao, Y. Corporate social performance in China: Evidence from large companies. J. Bus. Ethics 2009, 89, 23-35. [CrossRef]

25. Bai, C.; Sarkis, J.; Dou, Y. Corporate sustainability development in China: Review and analysis. Ind. Manag. Data Syst. 2015, 115, 5-40. [CrossRef]

26. Chen, Y.-C.; Hung, M.; Wang, Y. The effect of mandatory CSR disclosure on firm profitability and social externalities: Evidence from China. J. Account. Econ. 2017, 65, 169-190. [CrossRef] 
27. The 19th National Congress of the Communist Party of China. Available online: http://www.gov.cn/ zhuanti/19thcpc/baogao.htm (accessed on 16 May 2018).

28. Clarkson, P.M.; Li, Y.; Richardson, G.D.; Vasvari, F.P. Revisiting the relation between environmental performance and environmental disclosure: An empirical analysis. Account. Organ. Soc. 2008, 33, 303-327. [CrossRef]

29. Orlitzky, M.; Siegel, D.S.; Waldman, D.A. Strategic corporate social responsibility and environmental sustainability. Bus. Soc. 2011, 50, 6-27. [CrossRef]

30. Owen, D.L.; O'Dwyer, B. Corporate social responsibility: The reporting and assurance dimension. In The Oxford Handbook of Corporate Social Responsibility; Oxford University Press: Oxford, UK, 2008; pp. 384-409.

31. Miller, E.M. Risk, uncertainty, and divergence of opinion. J. Financ. 1977, 32, 1151-1168. [CrossRef]

32. Grossman, S.J.; Stiglitz, J.E. On the impossibility of informationally efficient markets. Am. Econ. Rev. 1980, 70, 393-408. [CrossRef]

33. Cordeiro, J.J.; Tewari, M. Firm characteristics, industry context, and investor reactions to environmental CSR: A stakeholder theory approach. J. Bus. Ethics 2015, 130, 833-849. [CrossRef]

34. Hasnas, J. The normative theories of business ethics: A guide for the perplexed. Bus. Ethics Q. 1998, 8, 19-42. [CrossRef]

35. Mitchell, R.K.; Agle, B.R.; Wood, D.J. Toward a theory of stakeholder identification and salience: Defining the principle of who and what really counts. Acad. Manag. Rev. 1997, 22, 853-886. [CrossRef]

36. Rodrigue, M. Contrasting realities: Corporate environmental disclosure and stakeholder-released information. Account. Audit. Account. J. 2014, 27, 119-149. [CrossRef]

37. Chen, S.; Sun, Z.; Tang, S.; Wu, D. Government intervention and investment efficiency: Evidence from China. J. Corp. Financ. 2011, 17, 259-271. [CrossRef]

38. Li, W.; Zhang, R. Corporate social responsibility, ownership structure, and political interference: Evidence from China. J. Bus. Ethics 2010, 96, 631-645. [CrossRef]

39. Liu, X.; Wang, C.; Wei, Y. Causal links between foreign direct investment and trade in China. China Econ. Rev. 2001, 12, 190-202. [CrossRef]

40. Kim, K.-H.; Kim, M.; Qian, C. Effects of corporate social responsibility on corporate financial performance: A competitive-action perspective. J. Manag. 2018, 44, 1097-1118. [CrossRef]

41. Lins, K.V.; Servaes, H.; Tamayo, A. Social capital, trust, and firm performance: The value of corporate social responsibility during the financial crisis. J. Financ. 2017, 72, 1785-1824. [CrossRef]

42. McGuire, J.B.; Sundgren, A.; Schneeweis, T. Corporate social responsibility and firm financial performance. Acad. Manag. J. 1988, 31, 854-872.

43. Oh, S.; Hong, A.; Hwang, J. An Analysis of CSR on Firm Financial Performance in Stakeholder Perspectives. Sustainability 2017, 9, 1023. [CrossRef]

44. Saeidi, S.P.; Sofian, S.; Saeidi, P.; Saeidi, S.P.; Saaeidi, S.A. How does corporate social responsibility contribute to firm financial performance? The mediating role of competitive advantage, reputation, and customer satisfaction. J. Bus. Res. 2015, 68, 341-350. [CrossRef]

45. Luo, Y.; Xue, Q.; Han, B. How emerging market governments promote outward FDI: Experience from China. J. World Bus. 2010, 45, 68-79. [CrossRef]

46. Unger, J. Bridges: Private business, the Chinese government and the rise of new associations. China Q. 1996, 147, 795-819. [CrossRef]

47. Becchetti, L.; Ciciretti, R.; Hasan, I. Corporate social responsibility, stakeholder risk, and idiosyncratic volatility. J. Corp. Financ. 2015, 35, 297-309. [CrossRef]

48. Tehulu, T.A. Determinants of financial sustainability of microfinance institutions in East Africa. Eur. J. Bus. Manag. 2013, 5, 152-158. [CrossRef]

49. Lourenço, I.C.; Branco, M.C.; Curto, J.D.; Eugénio, T. How does the market value corporate sustainability performance? J. Bus. Ethics 2012, 108, 417-428. [CrossRef]

50. Hunter, M.L.; Van Wassenhove, L.N.; Besiou, M.; Van Halderen, M. The agenda-setting power of stakeholder media. Calif. Manag. Rev. 2013, 56, 24-49. [CrossRef]

51. Besiou, M.; Hunter, M.L.; Van Wassenhove, L.N. A web of watchdogs: Stakeholder media networks and agenda-setting in response to corporate initiatives. J. Bus. Ethics 2013, 118, 709-729. [CrossRef]

52. Bruntland, G. World Commission on Environment and Development (WCED, 1987): Our Common Future; Oxford University Press: Oxford, UK, 1987. 
53. Atkinson, G. Measuring corporate sustainability. J. Environ. Plan. Manag. 2000, 43, 235-252. [CrossRef]

54. Inglehart, R. Public support for environmental protection: Objective problems and subjective values in 43 societies. PS Political Sci. Politics 1995, 28, 57-72. [CrossRef]

55. Nghiem, L.T.; Papworth, S.K.; Lim, F.K.; Carrasco, L.R. Analysis of the capacity of Google Trends to measure interest in conservation topics and the role of online news. PLOS ONE 2016, 11, e0152802. [CrossRef] [PubMed]

56. Choi, M.J.; Torralba, A.; Willsky, A.S. Context models and out-of-context objects. Pattern Recognit. Lett. 2012, 33, 853-862. [CrossRef]

57. Engle, R.F. Autoregressive conditional heteroscedasticity with estimates of the variance of United Kingdom inflation. Econ. J. Econ. Soc. 1982, 50, 987-1007. [CrossRef]

58. Franses, P.H.; McAleer, M. Financial volatility: An introduction. J. Appl. Econ. 2002, 17, 419-424. [CrossRef]

59. McAleer, M.; Oxley, L. The econometrics of financial time series. J. Econ. Surv. 2002, 16, 237-243. [CrossRef]

60. Li, W.; Ling, S.; McAleer, M. Recent theoretical results for time series models with GARCH errors. J. Econ. Surv. 2002, 16, 245-269. [CrossRef]

61. Ling, S.; McAleer, M. Necessary and sufficient moment conditions for the GARCH (r, s) and asymmetric power GARCH (r, s) models. Econ. Theory 2002, 18, 722-729. [CrossRef]

62. Ling, S.; McAleer, M. Asymptotic theory for a vector ARMA-GARCH model. Econ. Theory 2003, 19, $280-310$. [CrossRef]

63. Asai, M.; McAleer, M.; Medeiros, M.C. Asymmetry and long memory in volatility modeling. J. Financ. Econ. 2012, 10, 495-512. [CrossRef]

64. Marcucci, J. Forecasting stock market volatility with regime-switching GARCH models. Stud. Nonlinear Dyn. Econ. 2005, 9. [CrossRef]

65. Franses, P.H.; Van Dijk, D. Forecasting stock market volatility using (nonlinear) GARCH models. J. Forecast. 1996, 15, 229-235. [CrossRef]

66. French, K.R.; Schwert, G.W.; Stambaugh, R.F. Expected stock returns and volatility. J. Financ. Econ. 1987, 19, 3-29. [CrossRef]

67. Bollerslev, T. Generalized autoregressive conditional heteroskedasticity. J. Econ. 1986, 31, 307-327. [CrossRef]

68. Bollerslev, T.; Mikkelsen, H.O. Modeling and pricing long memory in stock market volatility. J. Econ. 1996, 73, 151-184. [CrossRef]

69. Chan, F.; McAleer, M. Estimating smooth transition autoregressive models with GARCH errors in the presence of extreme observations and outliers. Appl. Financ. Econ. 2003, 13, 581-592. [CrossRef]

70. McAleer, M.; Medeiros, M.C. A multiple regime smooth transition heterogeneous autoregressive model for long memory and asymmetries. J. Econ. 2008, 147, 104-119. [CrossRef]

71. McAleer, M. Automated inference and learning in modeling financial volatility. Econ. Theory 2005, 21, 232-261. [CrossRef]

72. Nelson, D.B. Conditional heteroskedasticity in asset returns: A new approach. Econ. J. Econ. Soc. 1991, 59, 347-370. [CrossRef]

73. Martinet, G.G.; McAleer, M. On The Invertibility of EGARCH (p, q). Econ. Rev. 2018, 37, 824-849. [CrossRef]

74. McAleer, M.; Hafner, C.M. A one line derivation of EGARCH. Econometrics 2014, 2, 92-97. [CrossRef]

75. Chang, C.-L.; McAleer, M. The correct regularity condition and interpretation of asymmetry in EGARCH. Econ. Lett. 2017, 161, 52-55. [CrossRef]

76. Baillie, R.T.; Bollerslev, T.; Mikkelsen, H.O. Fractionally integrated generalized autoregressive conditional heteroskedasticity. J. Econ. 1996, 74, 3-30. [CrossRef]

77. Chang, C.-L.; McAleer, M.; Tansuchat, R. Modelling long memory volatility in agricultural commodity futures returns. Ann. Financ. Econ. 2012, 7, 1250010. [CrossRef]

78. Shi, Y.; Ho, K.-Y. Modeling high-frequency volatility with three-state FIGARCH models. Econ. Model. 2015, 51, 473-483. [CrossRef]

79. Bentes, S.R. Measuring persistence in stock market volatility using the FIGARCH approach. Phys. A Stat. Mech. Appl. 2014, 408, 190-197. [CrossRef]

80. Cochran, S.J.; Mansur, I.; Odusami, B. Volatility persistence in metal returns: A FIGARCH approach. J. Econ. Bus. 2012, 64, 287-305. [CrossRef]

81. Belkhouja, M.; Boutahary, M. Modeling volatility with time-varying FIGARCH models. Econ. Model. 2011, 28, 1106-1116. [CrossRef] 
82. Taylor, D.; Shan, Y.G. What drives the fledgling practice of social and environmental reporting by Chinese companies listed in Hong Kong? Account. Account. Perform. 2007, 13, 55.

83. Mehran, H. Executive compensation structure, ownership, and firm performance. J. Financ. Econ. 1995, 38, 163-184. [CrossRef]

84. Jenter, D.; Kanaan, F. CEO turnover and relative performance evaluation. J. Financ. 2015, 70, $2155-2184$. [CrossRef]

85. Quitzow, R. Dynamics of a policy-driven market: The co-evolution of technological innovation systems for solar photovoltaics in China and Germany. Environ. Innov. Soc. Trans. 2015, 17, 126-148. [CrossRef]

86. Foley, H. Understanding Sustainability from a Global Perspective: Exploring the Role of Education for Sustainable Development within Contemporary Education in Ireland. Ph.D. Thesis, University College Cork, Cork, Ireland, 2017.

87. McAleer, M. Asymmetry and leverage in conditional volatility models. Econometrics 2014, 2, 145-150. [CrossRef]

(C) 2018 by the authors. Licensee MDPI, Basel, Switzerland. This article is an open access article distributed under the terms and conditions of the Creative Commons Attribution (CC BY) license (http://creativecommons.org/licenses/by/4.0/). 